\title{
A Numerical Study on Vibration Control of a Nonlinear Jeffcott Rotor via Bouc- Wen Model
}

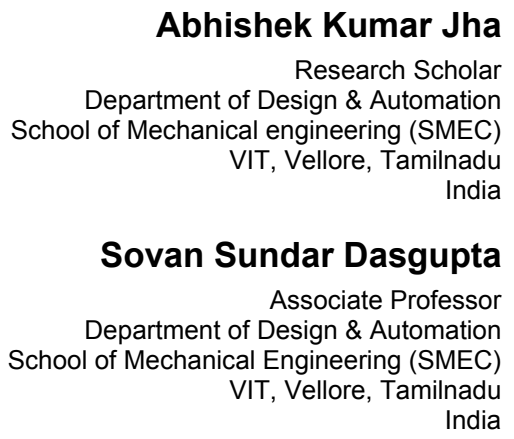

\section{INTRODUCTION}

Vibration attenuation of high speed rotating machines has received a considerable interest in the last few years. In high speed rotating machinery, such as gas turbine and compressors, rotating shafts are often subjected to vibrations which yield fatigue failure of the rotating components, excessive noise, instability and transmission of vibration to the supporting structure. The dynamical interaction among the stator and rotor and the mass unbalance are the main two reasons of their vibrations. In the present work, a modified Jeffcott rotor well discussed by Genta [1] with linear viscous damping and cubic stiffness excited by harmonic forcing function owing to mass unbalance is studied. Mass unbalance is commonly observed in high speed turbo-machinery due to many reasons such as manufacturing defect, material characteristics, nonuniform wear or corrosion, sticking of foreign particles etc. It causes whirling [2] of the shaft defined as the rotation of the plane made by the bent shaft and the line of centres of the bearing/support. Apart from that, instability phenomena in high speed rotors driven by a non-ideal source [3] owing to the presence of internal damping is of great importance in designing a controllable damping parameters for safe ruuning at high speeds.

Received: September 2018, Accepted: November 2018 Correspondence to: Dr Sovan Sundar Dasgupta

VIT, School of Mechanical Engineering,

Vellore, Tamilnadu, India.

E-mail: sovan@vit.ac.in

doi: $10.5937 /$ fmet1901190J

(C) Faculty of Mechanical Engineering, Belgrade. All rights reserved
In this work, instead of considering internal damping, non-ideal system issues, the attenuation whirl ampltide as a fallout of eccentricity between the centre of mass and the geometrical centre of the rotor disc via a special type of hysteretic damping model is primarily focused. It is well-known that especially at high speed, the impact of mass unbalance causes excessive whirl amplitude leads to catastrophic failure of the rotor system if not predicted and controlled properly.

Most of the scientific literature in rotor dynamics discussed the nonlinear dynamical aspects of machines and their interaction with non-linear bearings. Different faults such as rotor-stator rubs, cracked rotors have also been addressed extensively. However, only a few works are available so far which exploit the nonlinear characteristics of either passive support or dampers to reduce the whirl amplitude of the rotor-shaft. Das et al. [4] proposed an active vibration control approach to this problem. Vibrational response of rotor using passive support was studied by Dutta et al. [5]. Reduction the whirl amplitude using nonlinear springs is studied by Carrella et al. [6].

A variety of nonlinear hysteretic vibration absorbers/isolators such as electro- or magneto-rheological dampers have shown great promise in the field of vibration reduction due to their inherent hysteretic characteristics. Hysteresis is a typical nonlinear phenomenon, and encountered in many scientific fields. Recently, the role of squeeze film damper (SFD) to reduce the vibrational response was reported by several researchers [7,8]. Dutta \& Chakraborty [9] studied the performance of nonlinear oscillator with Magnetorheological (MR) damper based on hysteretic Bouc- 
Wen model [10,11]. In 2014, Balthazar and his coworkers [12] presented the attenuation and suppression of Sommerfeld effect [3] (a nonlinear jump phenomena which destabilizes the rotor system) using MR damper /device [13] through additional increase in current of the MR damper.

However, the application of hysteretic damping based on Bouc-Wen model has not been considered so far to reduce the whirl amplitude of rotor shaft.

The present work exploits the hysteretic characteristics of a special type of damping force based on a Bouc-Wen model to attenuate the whirling of a rotorshaft supported by nonlinear springs through numerical simulation. Over the years, many phenomenological models of hysteresis for mechanical systems have been proposed. One of the most widely accepted smoothly varying differential models is Bouc-Wen hysteresis model $[11,12,14]$. This model has been widely used to describe nonlinear hysteretic systems and this nonlinear differential equation model reflects local history dependence through introducing an extra state variable. Through appropriate choices of parameters in the model, it can represent a wide variety of softening or hardening smoothly varying behavior.

In the present study, our aim is to attenuate the whirl amplitude of a modified Jeffcott rotor with nonlinear cubic stiffness using hysteretic damping based on BoucWen model. Through appropriate choice of parameters of the model, a wide variety of hysteresis loops are obtained to illustrate the influence of Bouc-Wen parameters over the control of the loop size and smoothness. Following a numerical investigation to highlight the benefits of using Bouc-Wen hysteretic damping, time history and frequency response of the system are presented. A comparison between the responses of the system while using cubic stiffness and hysteretic damping reveals the effectiveness of Bouc-Wen hysteretic damping in reducing whirl amplitude in the subcritical range.

\section{MATHEMATICAL MODELLING AND APPROACHES}

A simple two degree of freedom (DOF) model of a Jeffcott rotor is considered in this study, as shown in Fig. 1. The rotor system is assumed to be symmetrical, so that the centre of mass of the disc is mid-way between two identical supports. Thus unbalanced force due to eccentricity $(e)$ applied at the centre of the rotor will only excite translational motion (as shown in Fig. 2). Furthermore both the flexible supports and the shaft are assumed to have negligible mass. The mass of the shaft is considered to be zero and it rotates with the angular speed $\omega$ along with phase .The springs are linear with overall stiffness (i.e., support and shaft) of $k_{x}$ and $k_{y}$. The viscous damping is a combination of the shaft structural damping, fluid damping due to the flow in turbo-machines, and the effective damping added by the bearings (as shown in Fig. 3 modeled as dashpot). In our present work the direct stiffness $k_{x}=k_{y}=k_{l}$ is considered only which produces radial force directed inward and collinear with the rotor deflection vector. The stiffness of the shaft experienced by the centrally mounted disk is
$K_{\mathrm{S}}=48 E I / L^{3}$, where $E I=$ flexural rigidity and $L=$ length of the shaft. The total stiffness provided by the supports (i.e. stiffness for individual identical bearing= $k_{b}$ connected in parallel) i.e., $K_{\mathrm{B}}=2 k_{\mathrm{b}}$. Now the $K_{\mathrm{S}}$ and $K_{\mathrm{B}}$ are connected in series. So the effective stiffness $k$ is given by $k_{1}=K_{\mathrm{S}} K_{\mathrm{B}} /\left(K_{\mathrm{S}}+K_{\mathrm{B}}\right)$.

The equations of motion of the shaft-disc system may be written as:

$$
\left.\begin{array}{l}
m \ddot{x}+c_{x} \dot{x}+k_{x} x=m e \omega^{2} \cos (\omega t+\phi) \\
m \ddot{y}+c_{y} \dot{y}+k_{y} y=m e \omega^{2} \sin (\omega t+\phi)
\end{array}\right\}
$$

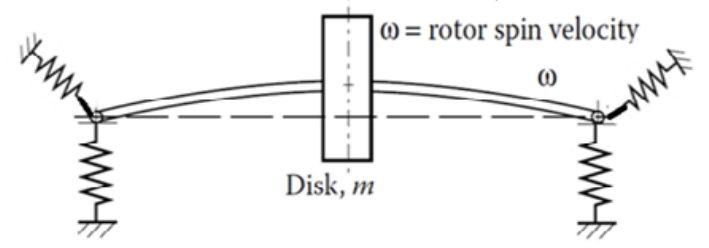

Figure 1. Schematic of shaft-disc system

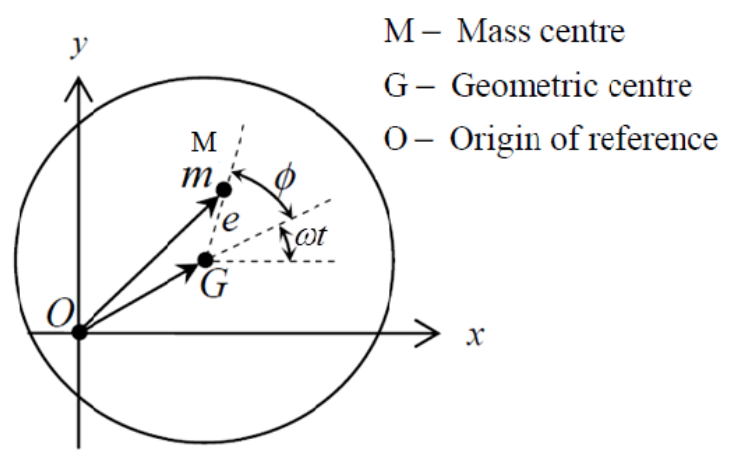

Figure 2. Positions of the geometric and mass centers of the rotor-disc.

The equations of motion are decoupled and apart from phase of the out-of-balance force, have the identical form. Thus we would analyse the generic equation in terms of the displacement $(q)$ and linear direct stiffness $k_{1}$ as:

$$
m \ddot{q}+c \dot{q}+k_{1} q=m e \omega^{2} \cos (\omega t+\phi)
$$

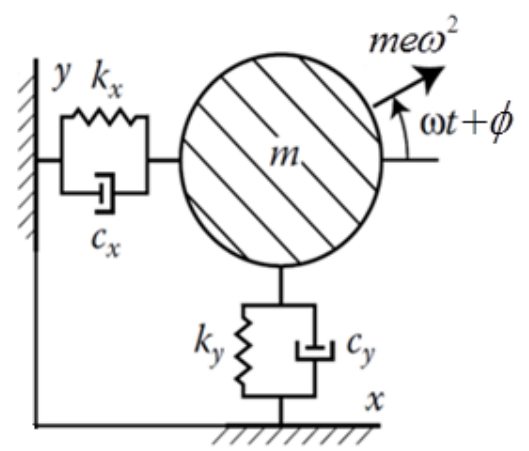

Figure 3. Orbital motion of the rotor disc in the radial $x-y$ direction connected through linear springs and dampers

The motion of the shaft is referred to as whirling. Excessive whirling may have catastrophic consequence for the integrity of the system. Lower amplitude whirling may result support vibration and noise and is usually reduced by balancing the machine or by the use of isolation mount. 


\subsection{Introduction of non-linear cubic stiffness and hysteretic damping terms}

Introducing nonlinear cubic stiffness term into Eq. (2) this becomes a non-linear Duffing equation of the following form:

$$
m \ddot{q}+c \dot{q}+k_{1} q+k_{3} q^{3}=m e \omega^{2} \cos (\omega t+\phi)
$$

The Duffing oscillator discussed by Nafey \& Mook [15] has been studied for many years, since it is representative of many nonlinear systems. Nonlinear cubic stiffness term appears due to either mid-plane stretching [16] of the shaft or by introducing nonlinear spring [6] at the supports. Nonlinear spring offers a lower natural frequency and reduces whirl amplitude compared to its linear counterpart.

In order to attenuate the whirl amplitude further, a hysteretic damping force $(z)$ based on Bouc-Wen model, following the approach presented in the reference [17] is added in the right hand side of Eq. (3) multiplied with a suitable scaling factor $(\gamma)$ and can be re-stated as:

$$
\begin{aligned}
& m \ddot{q}+c \dot{q}+k_{1} q+k_{3} q^{3}+\gamma z=m e \omega^{2} \cos (\omega t+\phi), \\
& \dot{z}=A \dot{q}-\alpha|\dot{q}| z|z|^{n-1}-\beta \dot{q}|z|^{n},
\end{aligned}
$$

where $\dot{z}=\frac{d z}{d t}$ and dot $(\cdot)$ represents differntiation with respect to time $(t)$.
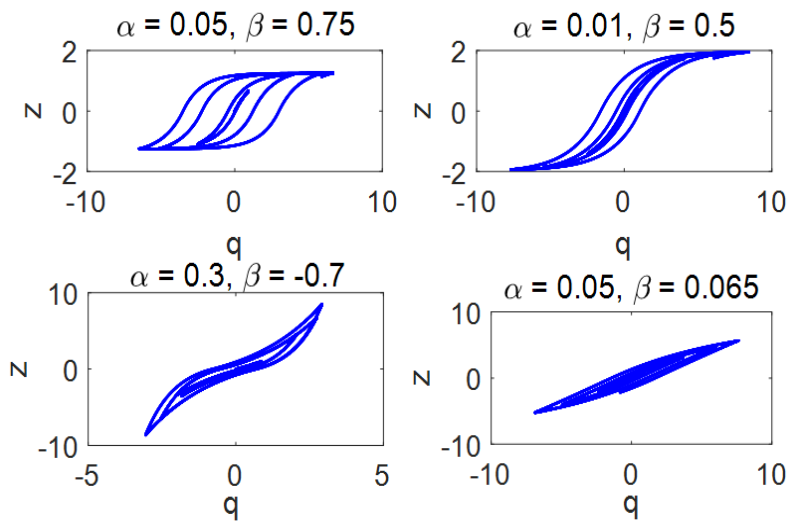

Figurer 4 . The hysteresis loop generated by Bouc-Wen model for various $\alpha$ and $\beta$ values.

Bouc-Wen model has been widely used to describe nonlinear hysteretic systems, which reflects local history dependence through introducing an extra state variable $(z)$ described by a nonlinear differential equation (shown in Eq. (5)).

In general, $A, \alpha, \beta$ influence the loop size and $n$ the smoothness of the loop. The hysteretic loops generated by Bouc-Wen model for different $\alpha$ and $\beta$ values are shown in Fig. 4. For the present study, the value of $A$ and $n$ both are taken as unity.

The Eq. (4) \& (5) then may be written in nondimensional form as follows:

$$
\begin{aligned}
& \bar{q}^{\prime \prime}+2 \varsigma \bar{q}^{\prime}+\bar{q}+\delta \bar{q}^{3}+\gamma \bar{z}=\Omega \cos (\Omega \tau+\phi), \\
& \bar{z}^{\prime}=A \bar{q}^{\prime}-\hat{\alpha}\left|\bar{q}^{\prime}\right| \bar{z}-\hat{\beta} \bar{q}^{\prime}|\bar{z}|,
\end{aligned}
$$

where

$$
\begin{aligned}
& \tau=\omega_{0} t, \bar{q}^{\prime \prime}=\frac{d^{2} \bar{q}}{d \tau^{2}}, q^{\prime}=\frac{d \bar{q}}{d \tau}, \bar{z}^{\prime}=\frac{d z}{d \tau} \bar{q}=q / e \\
& \delta=k_{3} / m, \varsigma=c / 2 m \omega_{n}, \omega_{n}^{2}=k_{1} / m, \bar{\gamma}=\gamma / m, \hat{\alpha}=\alpha e, \\
& \bar{z}=z / e, \hat{\beta}=\beta \text { e and } \Omega=\omega / \omega_{n} .
\end{aligned}
$$

All the parameters of rotor and Bouc-Wen model are presented in appendix in tabular form.

\section{NUMERICAL RESULTS AND DISCUSSION}

The following representative values are considered for the numerical simulation:

$m=2.2 \mathrm{~kg}, \Omega=0.9, \varsigma=0.1, \delta=0.4, \quad \phi=0.02, \alpha=$ $0.45, \beta=0.5$ and $e=0.1 \mathrm{~mm}$. The initial conditions are taken as $\left.\bar{q}\right|_{\tau=0}=0$ and $\left.\bar{q}^{\prime}\right|_{\tau=0}=0$.

Using the above parameters, the two normalized coupled equations i.e., Eq. (6) and (7) are simultaneously solved numerically through Runge-Kutta method (i.e., ode45 scheme in MATLAB).

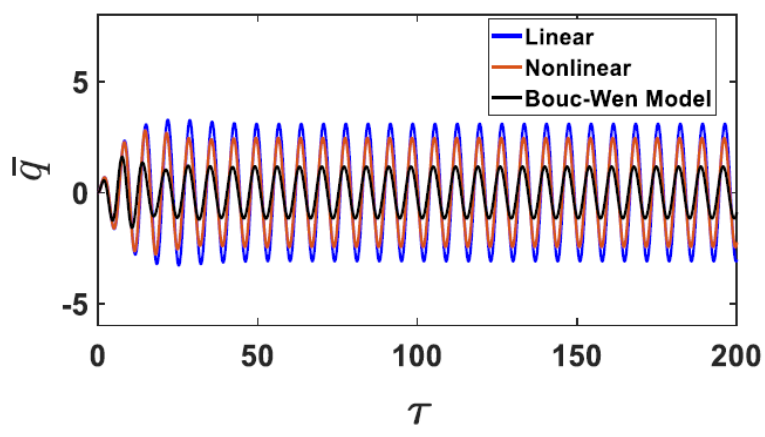

Figure. 5. Time response of the rotor to unbalance for subcritical range $\Omega<$ and $\bar{\gamma}=\mathbf{0 . 5}$ for linear, nonlinear cubic stiffness and hysteretic damping based on Bouc-Wen model.

In the subcritical range, i.e., $\Omega<1$, the time response of the rotor with hysteretic damping based on BoucWen model has a better stabilizing effect over the system with cubic stiffness as shown in Fig. 5.

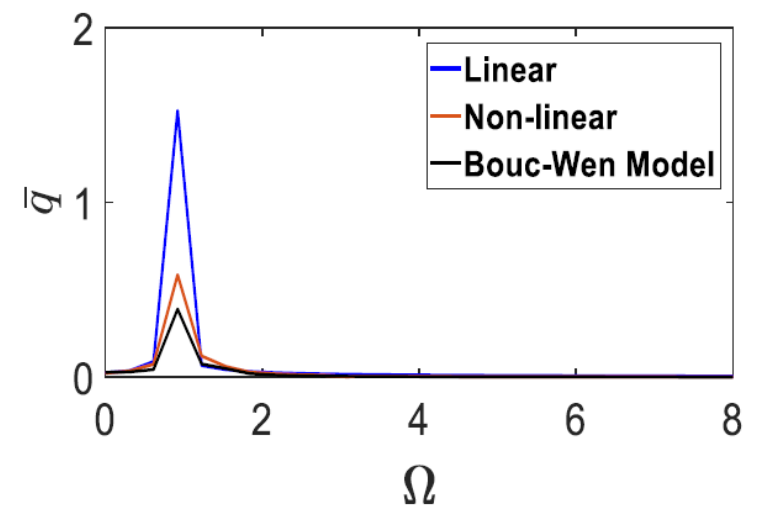

Figure 6. Frequency response of the rotor to unbalance for sub-critical range $\Omega<1$ and $\bar{\gamma}=0.5$ for linear, non-linear cubic stiffness and hysteretic damping based on BoucWen model.

Moreover, when the forcing frequency is lower than its critical speed i.e., in the subcritical range (i.e., $\Omega<$ 1), the whirl amplitude for the hysteretic damping (Bouc-Wen) is found to be the lowest in amplitudefrequency response (as shown in Fig. 6) compared to its 
linear and nonlinear counterparts. Thus it highlights the effectiveness of using Bouc-Wen hysteretic force in reducing whirling amplitude of the rotor system compared to its linear and cubic stiffness as reported by Carrella et al.,[6]. Further reduction of amplitude is made possible by increasing the scaling factor per unit mass of the $\operatorname{disc}($ i.e, $\bar{\gamma}=0.8)$ as shown in Fig. 7.

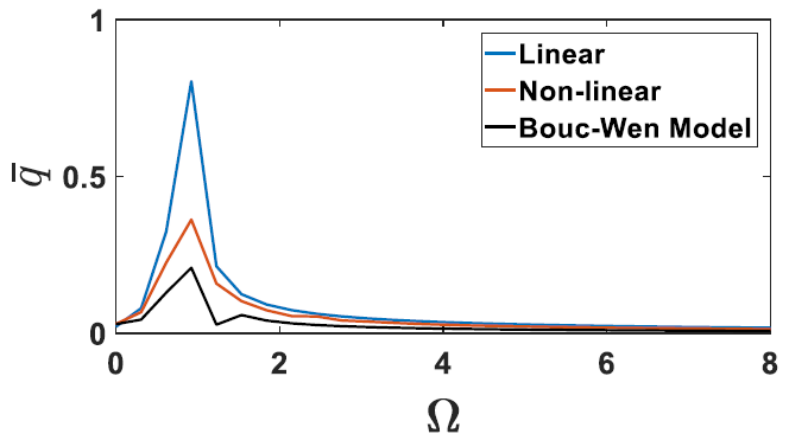

Figure 7. Frequency response of the rotor to unbalance for sub-critical range (i.e., $\Omega<1$ ) and $\bar{\gamma}=0.8$.

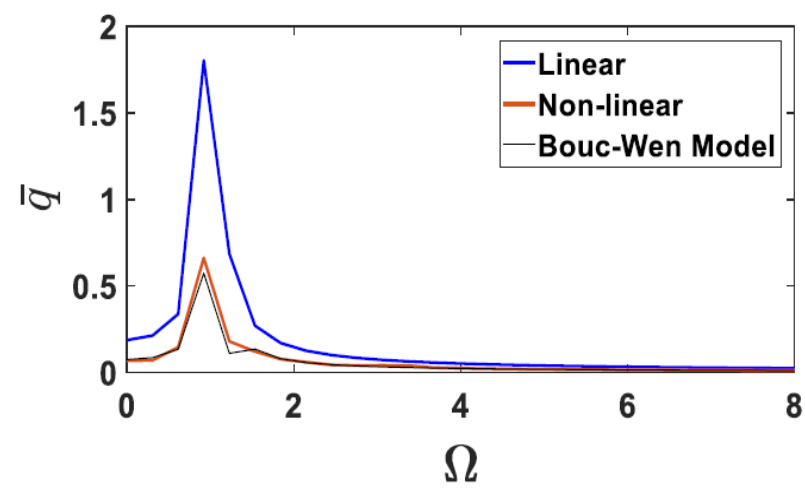

Figure 8. Frequency response for synchronous operation, (i.e., $\Omega<1$ ).

In synchronous operation i.e, $\Omega=1$, in which whirl frequency $\left(\omega_{n}\right)$ is same as the spin speed $(\omega)$, the BoucWen damping has almost no or very little effect in stabilizing the system (as shown in Fig. 8) compared to its nonlinear counterpart. Rather this phenomenon can be seen as a threshold wherein the effect of damping shifts from stabilizing to destabilizing [18].

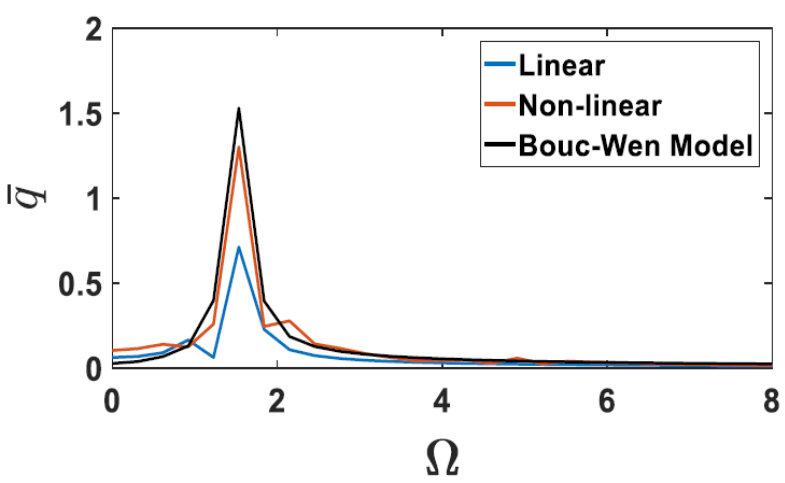

Figure 9. Frequency response of the rotor to unbalance for supercritical range ;']'pand $\bar{\gamma}=0.8$.

In the supercritical range of whirling i.e., $\Omega>1$, the whirl amplitude is found to be maximum (as shown in Fig. 9) i.e., instead of decreasing, it continues to go on increasing and leads to destabilize the system. The stabilizing and destabilizing effect of hysteretic damping of the rotating elements of a machine in subcritical and supercritical conditions respectively are very well known and has been reported in many papers. The results involving the present study are in good agreement with the above-mentioned results reported by the references $[1,18]$.

\section{CONCLUSION}

The vibration control of whirl amplitude of a nonlinear Jeffcott rotor is studied numerically using hysteretic damping based on Bouc-Wen model. From the time and frequency response diagrams, it is evident that in the subcritical range, the Bouc-Wen model based hysteretic damping yields better stabilizing effect compared to its linear and nonlinear stiffness models thus effectively reduces the whirl amplitude of the rotor. In synchronous operation, in which whirl frequency is same as the spin speed, the frequency of the hysteresis cycle is close to zero and Bouc-Wen damping has a very little or no stabilizing effect. In the supercritical operation, BoucWen model based hysteretic damping destabilizes the rotordynamic system above the critical speed. Therefore designers must then be careful when studying machines operating in the supercritical range and should avoid using hysteretic damping since it increases energy dissipation within the rotor (similar to material/internal damping, splined shaft and so on) and can cause severe instability problems. This work can be extended further by considering internal damping and gyroscopic forces in the rotor.

\section{ACKNOWLEDGMENT}

This research received no specific grant from any funding agency in the public, commercial or not for profit sectors. The authors declare no conflict of interest in preparing this article.

\section{NOMENCLATURE}

\begin{tabular}{cl}
$\begin{array}{c}\text { Symbol } \\
m\end{array}$ & \multicolumn{1}{c}{ Parameter } \\
$k_{x}, k_{y}$ & mass of the disc \\
$c_{x}, c_{y}$ & viscar spring stiffness in x and y directions \\
$e$ & unbalance eccentricity \\
$\omega_{n}$ & whirl speed of the rotor \\
$\omega$ & angular speed of the shaft/spin speed \\
$\phi$ & constant phase corresponding to the initial \\
$t$ & position of the mass center of the disk \\
$Q$ & time \\
$c$ & displacement of rotor in the generic \\
$k_{1}$ & Linear viscous damping \\
$k_{3}$ & Linear/effective direct spring stiffness \\
$Z$ & cubic spring stiffness \\
$\zeta$ & hysteretic force based on Bouc-Wen model \\
$\gamma$ & damping factor \\
$A, \alpha, \beta, n$ & Bcaling factor \\
$\tau$ & hysteresis loop size and smoothness \\
$\bar{q}$ & non-dimensional time \\
& non-dimensional whirl amplitude
\end{tabular}




\section{REFERENCES}

[1] Genta G.: Vibration of structures and machines, Springer, Berlin, 2012.

[2] Hartog J. Den.: Mechanical vibrations, Dover,New York, 1985.

[3] Dasgupta S.S., Rajan J. A.: Steady-state and transient responses of a flexible eccentric spinning shaft, FME Transactions, Vol. 46, pp.133-137, 2018.

[4] Das A.S., Nighil M.C., Dutt J.K., Irretier H.: Vibration control and stability analysis of rotorshaft system with electromagnetic exciters, Mech. Mach. Theory, Vol. 43, pp. 1295-1316, 2008.

[5] Dutt J.K., Nakra B.C.: Vibration Response Reduction of a Rotor Shaft System Using Viscoelastic Polymeric Supports, J. Vib. Acoust, Vol. 115, pp.221, 1993.

[6] Carrella A., Friswell M.I., Zotov A., Ewins D.J., Tichonov A.: Using nonlinear springs to reduce the whirling of a rotating shaft, Mech. Syst. Signal Process, Vol. 23, pp. 2228-2235, 2009.

[7] Zapoměl J., Ferfecki P., Kozánek J.: Modelling of magnetorheological squeeze film dampers for vibration suppression of rigid rotors, I.J. of Mechanical, Vol. 127, pp. 191-197, 2017.

[8] Ferfecki P., Zapoměl J., Kozánek J.: Analysis of the vibration attenuation of rotors supported by magnetorheological squeeze film dampers as a multiphysical finite element problem, Adv. Eng. Softw, Vol. 104, pp. 1-11, 2017.

[9] Dutta S., Chakraborty G.: Performance analysis of nonlinear vibration isolator with magnetorheological damper, J. Sound Vib. Vol. 333, pp. 5097-5114, 2014.

[10] Wen Y.: Method for random vibration of hysteretic systems, J. Eng. Mech, Vol. 102, pp. 249-263, 1976.

[11] Guida D, Pappalardo C.M., A new control algorithm for active suspension systems featuring hysteresis, FME Transactions, Vol. 41, pp. 285290, 2013.

[12]Piccirillo V., Tusset A.M., Balthazar J.M.: Dynamical jump attenuation in a non-ideal system through a magnetorheological damper, J. of Theo. and App. Mech. Vol. 52, No. 3, pp. 595-604, 2014.

[13] Fragassa C., Berardi L., Balsamini G.: Magnetorheological Fluid Devices: an Advanced Solution for Active Control of the Wood Manufacturing Process, FME Transactions, Vol. 44, pp. 333-339, 2016.
[14]Dobson S., Noori M., Hou Z., Dimentberg M., Baber T.: Modeling and random vibration analysis of SDOF systems with asymmetric hysteresis, Int. J. Non. Linear. Mech, Vol. 32, pp. 669-680, 1997.

[15] Nayfeh A.H., Mook. D.T.: Nonlinear oscillations, Wiley, New York, 1979.

[16] Thomsen J.: Vibrations and stability:advanced theory, analysis, and tools, Springer,Verlag Berlin Heidelberg, 2013.

[17]Li H., Meng G.: Nonlinear dynamics of a SDOF oscillator with Bouc-Wen hysteresis, Chaos, Solitons \& Fractals, Vol. 34, pp. 337-343, 2007.

[18] Genta G.: On a Persistent Misunderstanding of the Role of Hysteretic Damping in Rotordynamics, J. Vib. Acoust, Vol. 126, No. 3, pp. 459-461, 2004.

\section{НУМЕРИЧКО ПРОУЧАВАЫЕ УПРАВЉАЫА ВИБРАЦИЈАМА КОД НЕЛИНЕАРНОГ ЏЕФКОТОВОГ РОТОРА КОРИШЋЕЊЕМ БУК-ВЕНОВОГ МОДЕЛА}

\author{
А.К. Јха, С.С. Дасгупта
}

Рад се бави проучавањен нумеричког пригушивања амплитуда насталих при вртложном осциловању код Џефкотовог ротора са нелинеарном запреминском крутошћу применом хистерезишног пригушења базираног на Бук-Веновом моделу. Приказан је модификовани Џефкотов ротор са линеарним вискозним пригушењем и запреминском крутошћу побуђеном хармонијском функцијом сметње због неуравнотежене масе. Нелинеарни члан запреминске крутости се појављује или услед издужења вратила на средини равни или услед увођења нелинеарне опруге у подупирачима. Даље, у смислу пригушења вибрација у систем једначина се уводи нелинеарни члан хистерезишног пригушења, базираног на широко прихваћеном Бук-Веновом моделу, који се множи одговарајућим фактором размере. Адекватним избором параметара модела добијају се различите петље хистерезе које илуструју утицај параметара Бук-Веновог хистерезишног пригушења на управљање димензијама и уједначавањем петље. Показана је корист од нумеричког истраживања Бук-Веновог пригушења, развој и фреквенцијски одзив система. Извршено је поређење одзива система, док коришћење запреминске крутости и хистерезишно пригушење указују на ефикасност Бук-Веновог пригушења код редукције амплитуда насталих при вртложним осцилацијама у подкритичном распону. 